\title{
German Jews in Sweden
}

\section{Dialectics of symbiosis and coexistence}

Book Review

Deutschsprachige jüdische Migration nach

Schweden 1774 bis 1945, ed. Olaf Glöckner and Helmut Müssener, Europäisch-jüdische Studien Beiträge, Bd 33 (Oldenbourg,

De Gryuter 2017), xiv + 385 pp.

In November 2014 a research conference on German Jewish migration to Sweden in I774I 945 was held in Uppsala. It was organised by the Moses Mendelssohn Center for European-Jewish Studies, University of Potsdam, The Forum for Jewish Studies at Uppsala University, and Paideia: The European Institute of Jewish Studies in Sweden in cooperation with the Hugo Valentin Centre, Uppsala University. ${ }^{1}$ The conference papers are collected in the volume under review. In his preface one co-editor of the volume, Olof Glöckner of the Mendelsohn Center, mentions only the Center and the Forum as organisers; Paideia ${ }^{2}$ and the Hugo Valentin Centre ${ }^{3}$ are not mentioned. The fact that the Forum for Jewish Studies is part of the Department of Theology at Uppsala University is also not mentioned.

1 The International German-Jewish Migration to Sweden Conference website 2014.

2 Paideia: The European Institute for Jewish Studies in Sweden website.

3 'Research and Education at the Hugo Valentin Centre', The Hugo Valentin Centre website.

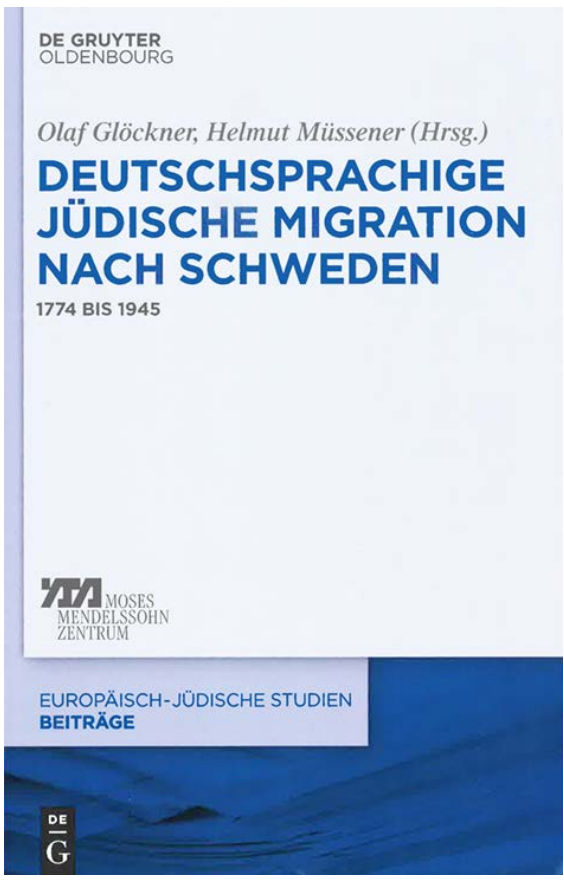

The preface gives short summaries of all the eighteen articles in the volume. It does not have any concluding chapter. There are no summaries of the articles. However, there is an exhaustive index of persons and an equally exhaustive list of literature (about 300 items). The latter enumerates works in Swedish and English by the individual contributors to the volume, thus indicating for non-German readers where and how to find materials with a bearing on the theme.

The volume fills a void in Swedish historiography on the history of Jews in Sweden up 
to I 945 . The second co-editor of the volume, Helmut Müssener, is Professor Emeritus of German Philology at Stockholm University and a senior researcher at the Hugo Valentin Centre. $\mathrm{He}$ is the single most influential scholar behind this endeavour: for half a century he has acted as a link between the Swedish Judaic research environment and German historical science. Thus the role of the Hugo Valentin Centre, Müssener's institutional locus, should have been mentioned in the preface to the conference volume.

The uniqueness of the conference on German-speaking Jews' migration to Sweden makes it mandatory to dwell on the special role of Müssener in Swedish research in this field. He has written the introductory chapter of the volume, a succinct overview of the state of art in this special field. Moreover, it enumerates a whole list of desiderata for new research on Swedish-German-Jewish relations.

Müssener presents the agenda concerning research on Swedish-German-Jewish relations in three introductory remarks. The first remark's point of departure is an allusion on the infamous declaration by Karl Lueger, the antisemitic mayor of Vienna from I 897 to I9 Io: 'I decide who is a Jew.' However, Müssener rescues the expression from its original antisemitic context through applying it as a characterisation of the operational definition of 'Jew' that was used by the pioneer of historical research on Jews in Sweden, Hugo Valentin (1888-r963). He was honoured by having his name bestowed on the research centre at which Müssener is active. Valentin oscillated between counting as Jews only people that were registered as members of the Jewish religious communities in Sweden on the one hand, and on the other hand people with 'Jewish surnames'. Müssener's argument is that Valentin's approach is 'exemplary': the identification of a person as Jewish lies in the eye of the beholder and must be made on a case-bycase basis.
Müsseners's second introductory remark bears the heading 'A late, a too late interest in the theme'. He observes that his own Habilitationsschrift in 1974 on the history of German refugees in Sweden during the Second World War (Müssener 1974) met with 'almost total disinterest' among Swedish scholars and for the most part also among German scholars. Müssener notes that in this work he omitted the role and significance of the Jewish refugees as a group and points out that this fact was not deplored in any review of the book (there were reviews in the popular press in Sweden and Germany). $\mathrm{He}$ adds that the theme of Jewish German refugees in Sweden continued to be met with lack of interest in German research until the r 980 s and in Swedish research until the late r99os. Because of this, Müssener observes, in the meantime many potential written sources were lost and almost all witnesses died off. Thus, the second task is to compensate for this negligence.

Müssener's third introductory remark is remarkable! Its heading is: 'Lack of knowledge of language as a barrier to research'. The author notes that a short article by him in Swedish on the German Jewish emigration to Sweden after I933, which was published in I975, has been cited much more often than his book Exil in Schweden (1975: 27-40). He ends his introductory remarks with words that made me choose to write this review in English and not in Swedish or in German (I want to address both communities in this review):

This [the fact that the short article in Swedish was preferred] does not depend on the outstanding quality of the article but on the lack of knowledge of German among Swedish scholars. The lack of knowledge of Swedish among German scholars would be the counterpart to this. The lack of knowledge of languages is a big problem that must be taken seriously. It makes access to sources limited or impossible. (Müssner I 975: 4) 
When one takes into consideration Müssener's remarks it comes as no surprise that his introductory chapter to this very substantial conference report ends with an enumeration of nine desiderata for research on the history of the Jewish minority in Sweden. The list of desiderata may be understood as a description of the lacunae in this research field.

Müssener argues that the still generally accepted sweeping statements by Hugo Valentin on Jewish history in Sweden must be overcome. His desiderata for further empirical research are:

\section{A generally valid description of the Swed-} ish-German-Jewish relations from I 933 to r 945 . So far, Müssener observes, the Swedish research has neglected the activities of Jews themselves and their supporters in Swedish society, anti-Nazis included, and instead has exhibited 'self-accusing flagellantism', and focused on the - certainly highly reproachable - restrictive Swedish refugee policy (tainted by antisemitism) concerning Jews fleeing from Nazi Germany.

2. The origins of German Jewish immigration in Sweden: who were the people, where did they settle, when did they migrate and what did they accomplish?

3. The success story or stories of a GermanDanish-Jewish immigration wave.

4. Rabbis and order of service in the synagogue.

5. 'The stupid Swedes': the issue of GermanSwedish-Jewish identity. Müssener observes that in the late nineteenth and early twentieth centuries Swedish anti-Jewish and anti-German prejudices coalesced. He refers to Lars M. Andersson's dissertation from 2000 on antisemitism in Swedish satirical journals. Andersson shows how the coalescence of German and Jewish resulted in Jews being portrayed as speaking a specific 'svyska', that is, a counterpart to Yiddish: in the Swedish context the difference between Yiddish and German was far from obvious. The antisemitic satirical point in Andersson's examples is that cunning Jews cheated what they called 'die dummen Schweden' (the stupid Swedes).

6. The business, entrepreneur and financial achievements of the (German-Swedish) Jews.

7. Sven Hedin, 'the sixteenth Jew'. The topicality of Sven Hedin (I 865-r952) is that he became notorious for his public support of Nazi Germany and Adolf Hitler. Hedin supported Germany during the First World War. In this capacity he was branded a Jew among anti-German antisemites, although he did not belong in any Swedish Jewish environment. Andersson gives ample examples of Hedin's antisemitic image (Andersson I 975: I 25, 275, 368).

8. German and Swedish antisemitism. This desideratum is, in a nutshetll, a quest for research into the putative heavy German influence upon the Swedish antisemitic discourse which was the subject of Andersson's dissertation.

9. The image of the Ostjuden (Eastern Jews, i.e. poor, Yiddish-speaking Jews from the Russian empire).

Müssener's desiderata demonstrate the close relationship in Swedish perceptions between Jewish and German. The once celebrated idea of a German-Jewish symbiosis rang true in Sweden, although in an antisemitic discourse. 4

4 Antisemitism is directed against human beings. It is not directed against an ideology. The word should therefore be spelled in one word with a small 'a' and without a hyphen. Cf. Langmuir I 990. 
Jews were simply perceived as a worse kind of Germans. The positive symbiosis was, up to the I950s, a symbiosis between Swedish Jews and German Jews. In the first paragraph of the conference volume Müssener declares that whereas in historiography one often meets statements on the 'frequent relations between Swedish and German Jewry' this is an understatement: 'It is rather a permanent relationship, almost a symbiosis' (p. I).

Anyhow, it is evident that the beneficial impact in Sweden of German culture is to a certain degree the result of the activities of German Jews who - many involuntarily - settled in Sweden. Henrik Rosengren's study of the activities of five Jewish German musicians and musicologists in Sweden after 1933 demonstrates this (Rosengren 20I3, 20I6).

Müssener mentions that there is in contemporary Sweden a research network named 'The Jews in Sweden: The History of a Minority'. He argues that the network should be re-named 'The Jews in Sweden: The History of an Exemplary Minority'. He adds in conclusion that future research according to his own agenda, the nine desiderata, will demonstrate not only the broad scope of Swedish-GermanJewish relations but also their beneficial significance for the Jewish minority in Sweden and, above all, for Sweden.

Deutschsprachige jüdische Migration nach Schweden 1774 bis 1945 has five themes: I. Immigration traditions and family narrations (four articles); 2. German-speaking Jews and their influence on the Jewish community in Sweden (community is here understood not as a religious but as an ethnic entity, three articles); 3. Fates varying between escape, exile and re-start (four articles); 4. Refugee assistance and self-organisation in 1933-45 (three articles); and 5 .'rescue operations for children and youngsters, I 933-45 (three articles).

Three of the contributions are summaries of monographs that have been published previously in Swedish. A fourth contribution is a follow-up to the author's dissertation. One of the summaries is the study of five exiled musicians by Henrik Rosengren, mentioned above. The book has also been published in German. It does not meet any of the specific criteria of Müssener's desiderata, but focusing on musicians and musicologists it contributes to the 'success' agendas of desiderata 3 and 6 (Rosengren 2013, 2016). Rosengren shows that 'success' must not be interpreted as indicating individual happiness. It needs to be understood as an indication that the individual managed to make a professional career in the new environment.

Harry S. Svensson tells the commercial and social success story of a Swedish family of the so-called Port Jews, the family RubenPhilip that stemmed from Hamburg and settled in Karlskrona. The dissertation was published in Swedish in 20r7. It meets Müssener's desideratum 2. Malin Thor Tureby records the intriguing history of German Jewish Zionist Youth refugees in Sweden in the r93os and early i 940s. Her dissertation was published in Swedish in 2005. By focusing on the activities of the so-called Halucha movement, the dissertation was a step towards meeting the criteria of Müssener's desideratum I.

Carl Henrik Carlsson's research focus has been on the immigration of Ostjuden in the early twentieth century and their precarious initial years in Sweden, precarious because they came from the Russian empire, were orthodox and spoke Yiddish. Carlsson's dissertation was published in Swedish in 2004. It meets Müssener's desideratum 9 and has the eloquent title 'Citizenship and discrimination' (Carlsson 2004). Carlsson's contribution to the conference volume is a follow-up to his dissertation. He zooms in on one individual, Jacob Ettlinger, whom Carlsson designates as 'not a typical German Jew in Sweden'. Ettlinger stemmed from Mannheim, where he was born in I 880 . In I 9 I 5 , he arrived in Stockholm as a branch-office 
manager of a company in ore and metals, where 'all [offices] were led by Jews in a kind of family and friends network' (p. 53). Ettlinger remained in Stockholm until his death in 1952.

A cursory glance at Ettlinger's story would see him emerge as an archetypical German Jew in Sweden in line with the story of the Ruben-Philip family and a number of success stories of co-brethren in Stockholm and Gothenburg. However, by outlining the Jewish social history of Stockholm, Carlsson explains why Ettlinger was not a 'typical German Jew'. There was a sharp difference between the two Jewish environments in early-twentieth-century Stockholm. The 'typical German Jews' stemmed from immigrants from Germany in the late eighteenth and nineteenth centuries. They belonged to the world of entrepreneurs, bankers, academics, artists and professionals. They were integrated into the Swedish bourgeoisie and were usually adherents of Reform Judaism. In Stockholm they lived on the city's north side, Norrmalm and Östermalm. Fredric Bedoire has written the story of how these people created banks, art galleries, publishing houses and department stores and the whole new district of the North Side, which became the financial centre of Sweden, a counterpart to the City of London and Wall Street in Manhattan (Bedoire 2004). The work by Fredric Bedoire referred to here (it was published in its original Swedish in 1998) may be viewed as an inventory of approaches that belong to Müssener's desideratum 6.

The Ostjuden lived in the labour district, the South Side, in Södermalm. They were artisans and workers, and rather poor. They were Orthodox and Yiddish-speaking. Jacob Ettlinger identified with the latter in terms of religious observation. In different ways he supported the poor Orthodox Jewry in the south: the reformers and the Orthodox constituted one single religious community but they went to different synagogues, the first to the modern temple on the North Side, the later to a rather unobtrusive house on the South Side.

Whereas all contributions to the conference and volume serve to increase knowledge of the Swedish-German-Jewish triad, three of them stand out. 'the first is a fine example of chutzpa among Swedish Judaist scholars, the second is personal and at the same time 'typical' as a story of the trajectory of intellectual Germanspeaking immigrants in Sweden and of their offspring - an example of a success story - and the third widens the scope into cosmopolitanism and 'bivalence' (the concept will be defined below) with a Jewish dimension.

In her contribution 'Gottlieb Klein and Religionswissenschaft 5 in Sweden' Lena Roos tells the story of a German rabbi in Stockholm, Gottlieb Klein (I852-r9r4), who became a Swedish patriot and befriended the professor of theology, Nathan Söderblom (I866-r93 I, from I9I4 archbishop). Klein and Söderblom were together instrumental in promoting a chair in the history of religion at Stockholm University. Roos's thought-provoking analysis of the research-political symbiosis between the Jew and the Lutheran ends with the suggestion of celebrating the centenary of Klein's death (Roos uttered this during the conference, which took place one hundred years after Klein's death) through the establishment at Uppsala University of a Department of Jewish Studies. It stands to reason that Lena Roos is Head of the Forum for Jewish Studies at the Department of Theology in Uppsala.

5 In Swedish and German the translation into 'science of religion' is wrong; Roos's own Department of Theology at Uppsala University uses the rather cumbersome wordings 'Religionshistoria och religionsbeteendevetenskap; Religionshistoria' and 'History of Religions and The Social Sciences of Religion; History of Religions', see 'Lena Roos', Uppsala University website. 
In Sweden as elsewhere people who identify as Jews are statistically over-represented in Jewish studies. A special case is those who can tell the story of their family and/or of themselves in a manner that makes it emerge as typical of a whole category of Jews. Lars Dencik's contribution to the conference volume has the heading 'Exile: despair and creativity'. It is by far the longest article in the volume, comprising a seventh of it. It is also the most comprehensive. The main protagonist is Dencik himself, who was born in Sweden in I94I as the first child of refugee immigrants from Czechoslovakia and has made a successful academic career as a scholar and teacher in psychology in Sweden, Denmark and Germany. 6

Dencik's archetypic example of despair and creativity in exile is the Nobel laureate in literature (1966), Nelly Sachs. A poem by Sachs about a butterfly is cited as an epigraph to his article. According to Dencik, the four phases of the life of the butterfly, from egg through caterpillar and pupa into butterfly, are a suitable metaphor for describing the fate of a Jew. He argues that Jewish life in general in every time and every place has been life in exile. As applied to creative Jewish German refugees who became successful professional artists and scientists in Sweden, Dencik argues that the butterfly metaphor should be limited to the monarch butterfly (danaus plexippus): it covers huge distances, finally to return to its place of origin. However, it is not the original butterfly that returns but its descendants. Dencik enumerates many 'success' stories in this vein. The most eloquent example which he mentions besides Nelly Sachs, who received her Nobel Prize as a writer in German, is the playwright Peter Weiss. However, Dencik does not remain in the realm of lofty metaphors. He ends his autobiographical essay with a plea for the Jew as the eternal cosmopolite: 'the "we", without which nobody can exist, should never

\section{6 'Lars Dencik', Wikipedia.}

be fixed upon the territory or nation where one was born' (p. IO2).

Lars Dencik's plea for cosmopolitanism should be understood as a reaction against identity policies in contemporary Sweden and its neo-racist agenda. Endorsing Hanna Arendt's theory of political federalism, Nathan Sznaider has emphasised that 'cosmopolitanism combines appreciation of difference and diversity with efforts to conceive of new democratic forms of political rule beyond the nation-state' (Sznaider 2OII: 5). This political programmed is entailed by Dencik's declaration.

It is noteworthy that Anders Hammarlund's contribution to the conference volume conceptualises its theme in Dencik's vein. The title of the article is intriguing: 'Lazarus-SimmelBoas: on the legacy of the science (Wissenschaft) of/on Jewry (des Judentums)'. The point of departure for this article is a study by Hammarlund which he published in 2013 in Swedish and English about a German Jew, Abraham Baer, who arrived in Gothenburg in the mid-nineteenth century and remained there until his death (Hammarlund 20r3a, 20r3b). In this study Hammarlund demonstrates how in nineteenth-century Gothenburg Jews became Swedes as bearers and innovators of a SwedishEuropean cultural heritage. His primary example is the life and career of Abraham Baer. Baer was born in I834 into a learned Jewish family in Prussia. He chose not to become a Talmudist rabbi but did become a cantor. He was hired by the Jewish community in Gothenburg in 1857 and remained there until his death in 1894 . With Baer's rich social life among the Jewish bourgeoisie in Gothenburg in focus, Hammarlund paints the picture of the crucial Jewish contribution to the emergence of modern Swedish city culture. In this connection it must be added that according to Fredric Bedoire, Gothenburg housed the most radical and modernist people among the Swedish Jews. Their contributions to architecture, art, education, industry and science 
were of crucial importance for the development of Gothenburg into a liberal centre of Swedish culture and into a major industrial city (Bedoire 2004).

In his conference contribution Hammarlund describes the intellectual background of Baer, thereby presenting 'the role of the Jewish reform movement in I9th century German culture, especially its significance for the emergence of the modern social and humanistic sciences after I 850 ' (Hammarlund 20 I 3 b: I36). Hammarlund refers to some other scholars/intellectuals besides the three who are mentioned in the title of his contribution. His tour de force has a strong family resemblance with Lars Dencik's approach.

Dencik's argument on cosmopolitanism undermines the simplistic notion of applying 'national' adjectives not only to individuals but also within historical writing. The majority of the remaining contributions to the conference volume therefore should be read not only as 'Jewish' stories but as historical narrations in their own right about the scourge of ethnic nationalism and about how people managed to defy it. Some of the articles are short biographies of remarkable people in the hyphenated Swedish-German-Jewish cohort: Nelly Sachs, Hans-Joachim Schoeps, Isaak Feuerring, Gottfried Bermann Fischer, Lotte Laserstein and the five musicians and musicologists that have been referred to above.

The volume contains six stories of rescue of Jews from Germany and Austria in the r 930 s and I 940s. Among these, Pär Frohnert's analysis of the activities of the Christian organisation, the Swedish Israel Mission, is especially noteworthy. It takes issue with earlier studies that have given the impression that the goal of the Christian endeavour was to save only baptised Jewish children and youngsters (cf. Koblik I988). A book by Elisabeth Åsbrink on the fate of a rescued boy from Vienna, Otto Ullman, who became a worker at the farm of Ingvar Kamprad's family, aroused great public interest in Sweden. The young Kamprad, who at this time was a Nazi, befriended Otto (Åsbrink 20I I, 20I4). At the time Åsbrink's book was published Kamprad was very well known not only as the founder of the IKEA company but also because of his Nazi past (Sjöberg I 998). Frohnert argues that Åsbrink downplays the humanitarian motives behind the rescue operations. According to Frohnert, her thesis that the Swedish Israel Mission's single interest was to rescue converted Jewish souls and not to save lives has no support in the primary source material. Moreover, Åsbrink has neglected earlier Swedish research on the rescue operation of the Swedish Israel Mission (Edvardsson I 976; Lomfors I 996).

Lars Dencik's plea for cosmopolitanism has an air of ironic allusion to Stalin's infamous antisemitic campaign in the Soviet Union after the war (Pinkus 1984). One may argue that Dencik's description should not be limited to the Jewish experience: it is possible to widen the scope and make the description universal. The Polish scholar Antonina Kloskowska once suggested the concept of 'bivalence' to denote 'non-conflicting interlinking of elements selected from two cultures, possessed, approximately, in the same degree and accepted as close to one's value system' (Kloskowska r 994: 92). She adds 'bivalence' to Zygmunt Bauman's concept of 'ambivalence', which the latter used to describe the attitudes among West European Jewry towards their 'host' nations after emancipation and before the rise to power of the Nazis in Germany (Bauman r 99I). Kloskowska argues that Bauman's concept may be self-contradictory and can denote something negative, a love-hate stance. Her own aim is to introduce a concept with ethnically positive connotations.

Another approach to bivalence is to write about symbiosis (cf. Gerner 201 8). It is adequate to recall the state of the Jews in Germany. After the emancipation of the Jews in the German Reich in I87 I the concept 'symbiosis' was used 
to describe this historical relation (Sauerland 200I). After I 933 it turned out to have been an illusion (Elon 2002: I I). Riccardo Calimani writes about 'the illusion of integration' of the Jews in Berlin. The alleged symbiosis was realised only in some individuals or within small groups but never became a central developmental trait. Even in the Weimar period, only a minority of Jews were part of German cultural life (Calimani I 996: 33 I-2).

In Spanish one used instead of symbiosis the term convivencia, which did supposedly comprise Jews, Muslims and Christians (cf. Mann et al. 1992). This can be interpreted to indicate not symbiosis but peaceful coexistence of distinct cultures. The late Jewish-Polish-English sociologist Zygmunt Bauman in one of his last articles, published only posthumously, argued that 'la convivenza' of individuals was the only way to solve social conflicts in the contemporary European states that have recently received a huge number of refugee-immigrants:

It is not easy to live together with strangers, with the differences that they incarnate. We shall not make any illusions about changing others. However, it would be wise, necessary, to attempt to solve the real problems caused by the immigration. In this manner we can create an art of life and live together. This is the ultimate answer to the real problems created by the migrant phenomenon: the art of living. (Bauman 201 8: 24-5, translation to English by Kristian Gerner)

Thus, at the end of his life, Bauman exchanged ambivalence for the more benign concept of coexistence. Whereas the concepts of bivalence and ambivalence refer to the identification of individuals, the concept of symbiosis indicates the merger of two cultures into a new entity. The concept of coexistence refers to the definition of different cultures. This view of society is reminiscent of Arend Lijphart's theory of the consociational democracy (Lijphart 1977).

Whereas the convivencia in Spain lasted for almost eight centuries, the Jewish-Gentile symbiosis in Germany lasted for only six decades. Two and a half centuries of the life of Jews in Sweden have been marked by the dialectics of symbiosis and coexistence: symbiosis with German Jewry until the r 950s and lasting coexistence with non-Jewish Swedes.

\section{KRISTIAN GERNER}

Kristian Gerner is Professor Emeritus of History, Lund University. His research and journalism has focused on twentieth century Russian (Soviet) Central and East European, and European Jewish history and historical culture. Publications include 'Ambivalence, bivalence and polyvalence: historical culture in the GermanPolish borderlands' in Echoes of the Holocaust (Nordic Academic Press 2003); 'The Holocaust and Jewish-Polish-German historical culture', in Festskrift till Anders Fogelklou (lustus 2008).

\section{References}

Andersson, Lars M., 200o. En jude är en jude är en jude. Representationer av "juden" $i$ svensk skämtpress omkring 1900-1930 (Lund, Symposion)

Åsbrink, Elisabeth, 20I I. Och i Wienerwald står träden kvar (Stockholm, Natur och Kultur)

-20I4. Und im Wienerwald stehen noch immer die Bäume. Ein jüdisches Schicksal in Schweden (Zurich \& Hamburg, Arche Literatur Verlag)

Bauman, Zygmunt, I 99 I. Modernity and Ambivalence (Cambridge, Polity Press)

-20 1 8. La luce in fondo al tunnel. Dialoghi sulla vita e la modernitá (Milano, San Palo)

Bedoire, Fredric, 2004. The Jerwish Contribution to Modern Architecture, 1830-1930 (Jersey City, KTAV Publishing House, Inc.)

Calimani, Riccardo, I 996. I destini e le aventure dell'intelletuale ebreo 1650-1933 (Milano, Mondadori)

Carlsson, Carl Henrik, 2004. Medborgarskap och diskriminering. Östjudar och andra invandrare i Sverige, 1860-1920 (Uppsala, Historiska institutionen)

Edvardsson, Lars, I 976. Kyrka och judendom. Svenskjudemission med särskild hänsyn till Svenska Israelmissionens verksambet 1875-1975 (Lund, Liber/Gleerup) 
Elon, Amos, 2002. The Pity of it All: A History of Jews in Germany, 1743-1933 (New York, Metropolitan Books)

Gerner, Kristian, 20 I 8. 'Ethnic triangles, assimilation and the complexities of acculturation in a multi-ethnic society: the Jewish dimension in Polish and Hungarian historical culture', Poland and Hungary: Jewish Realities Compared, ed. François Guesnet, Howard Lupovitch, and Anthony Polonsky, Polin: Studies in Polish Jewry, 3 I (forthcoming)

Hammarlund, Anders, 2013 a. En bön för moderniteten. Kultur och politik i Abraham Baers värld (Stockholm, Carlssons)

_20 I3b. A Prayer for Modernity: Politics and Culture in the World of Abraham Baer (1834-1894), <https://musikverket.se/ svensktvisarkiv/files/2013/o6/Online publ_A_Prayer_for-Modernity.pdf> (accessed 24.4.2018)

Kloskowska, Antonina, I 994. 'National conversion: a case study of Polish-German neighbourhood', The Neighbourhood of Cultures, ed. Richard Grathoff and Antonina Kloskowska (Warsaw, Institute of Political Studies)

Koblik, Steven, I 988. The Stones Cry Out: Sweden's Response to the Persecution of the Jews, 19331945 (New York, Holocaust Library)

Langmuir, Gavin I., I 990.Towards a Definition of Antisemitism (Berkeley, University of California Press)

'Lars Dencik', Wikipedia, <https://sv.wikipedia. org/wiki/Lars_Dencik> (accessed 29.4.201 8)

'Lena Roos', Uppsala University website, <http:// katalog.uu.se/empinfo/?id=N96-2574> (accessed 29.4.201 8)

Lijphart, Arend, I 977. Democracy in Plural Societies: A Comparative Exploration (New Haven, Yale University Press)

Lomfors, Ingrid, I 996. Förlorad barndom återvunnet liv. De Judiska flyktingbarnen från Nazityskland (Göteborg, Historiska institutionen)

Mann, Vivian B., Thomas F. Glick and Jerilynn D. Dodds (eds.), 1992. Convivencia: Jerws, Muslims and Christians in Medieval Spain (New York, The Jewish Museum)

Müssener, Helmut, I 974. Exil in Schweden: politische und kulturelle Emigration nach 1933, Acta Universitatis Stockholmiensis, vol. I4 (München, Hanser)

- 975 . 'Den tysk-judiska emigrationen till Sverige efter I 933', Nordisk Judaistik I 975, pp. $27-40$
Paideia: The European Institute for Jewish Studies in Sweden, <http://www.paideia-eu. org/ $>$ (accessed 24.4.2018)

Pinkus, Benjamin, 1 984. The Soviet Government and the Jerws, 1948-1967: A Documented Study (New York, Cambridge University Press)

'Research and Education at the Hugo Valentin Centre', The Hugo Valentin Centre website, $<$ https://www.valentin.uu.se/about-us/> (accessed 24.4.2018)

Rosengren, Henrik, 2013. Från tysk höst till tysk vår. Fem musikpersonligheter $i$ svensk exil $i$ skuggan av nazismen och kalla kriget (Lund, Nordic Academic Press)

2016. Fünf Musiker im Schwedischen Exil. Nazismus - Kalter Krieg - Demokratie. Musik im "Dritten Reich" und im Exil (Hamburg, Von Bockel Verlag)

Sauerland, Karol, 200 I. 'Im Namen einer deutschjüdischen Symbiose: Hermann Cohen', Jüdische Intellektuelle und die Philologien in Deutschland, 1871-1933, ed. Wilfried Barner and Christoph König (Marbach, Wallstein Verlag)

Sjöberg, Thomas, I 998. Ingrvar Kamprad och hans IKEA. En svensk saga (Stockholm, Gedin)

Svensson, Harry S., 20 I 7. Fabian Philip, familjen Ruben och örlogsstaden. Entreprenörsfamiljen som grundade Mosaiska församlingen i Karlskrona 1780-1945 (Stockholms universitet)

Sznaider, Natan, 20 I I. Jewish Memory and the Cosmopolitan Order (Cambridge, Polity Press)

The International German-Jewish migration to Sweden conference, 20I4. German-Jewish Migration to Sweden: Interdisciplinary Perspectives on History, Identity and Religion, Uppsala, November 5-7, 2014 , Department of Theology, Uppsala University, < http:// www.teol.uu.se/about-us/the-forum-forjewish-studies/seminarier-och-konferenser/ international/ $>$ (accessed 24.4.2018)

Thor, Malin, 2005. Hechaluz - en rörelse i tid och rum. Tysk-judiska ungdomars exil i Sverige 1933-1943 (Växjö universitet) 